\title{
Performance of Banks in Pakistan based on determinants of Profitability
}

\author{
AQSA SIDDIQ \\ Assistant Professor, University of Peshawar \\ KHURSHEED IQBAL \\ Assistant Professor, Brains Degree Postgraduate College \\ SHAMS UR REHMAN \\ Assistant Professor, Qurtaba University Peshawar
}

\begin{abstract}
The study aims to seek the internal factors that affect the profitability of banks in Pakistan from a period of 2009 to 2013 by using two proxies i.e. Return on Assets (ROA) and Return on Equity (ROE). The panel data of fifteen banks have been obtained from the financial statements of the banks. Therefore, Hausman test has verified that random effect model is most appropriate model for Return on Assets (ROA), conversely fixed effect model is prominent for Return on Equity (ROE) for the current study. The empirical results confirm that investment to total assets, leverage, Net Performing Loan (NPL) to gross advances, capital ratio and total deposits to total equity are the main determinants of profitability across both proxies (i.e. ROA and ROE). Leverage and capital ratio have significantly negative, however net performing loan to gross advance and total deposit to total equity have significantly positive influence on profitability of banks across both models. Moreover, NPL to gross advance is insignificant determinant of Return on Equity. The results are worthy for bankers and all stakeholders to make strategic decision for the competitiveness of banking sector in Pakistan.
\end{abstract}

Key words: Bank, Profitability, ROA, ROE, Fixed and Random Effect Model

\section{Introduction}

Financial institutions as effective intermediaries flow funds through economic units to support trade and commerce. Under the common legislative arrangement, the administrative responsibilities of banks, Development Finance Institutions (DFIs), and Microfinance Banks (MFBs) fall within the legal domain of State Bank of Pakistan (State Bank of Pakistan, 2009). The smooth operation of the economic system is possible due to the efficient operation of the banking sector. However, the industry gets remarkable attention from corporate managers, researchers and the diverse stakeholders around the world. The main goal of any firm is to maximize the wealth of shareholders by practicing best performance in term of efficient utilization of resources (Gitman, 2007). Furthermore, performance of a firm can be affected with two types of factors (i.e. internal and external factor). The internal dimensions include firm's policy, decision and management style. On the other hand, the external dimensions are macroeconomic 
variables. The empirical study of Albertazzi and Gambacorta (2009) concludes that the relationship of profitability and overall business cycle is essential for the assessment of stability. The financial sector of economies is based on banking system to carry out all financial transactions. Thus, some factors like capital, management decisions, cost management, poor quality, poor liquidity, and ineffective management can directly affect the performance of the sector. In the last few years the banking sector of Pakistan showing incredible performance, however if it is compared to international market, the industry faces lack of efficiency, and competitiveness that reflects low performance and stability. The ultimate goal of businesses is to increase their productivity and profitability. Therefore, banks are trying to manage cost, strengthen customer relationship, and develop products mix and pricing strategies. Thus, performance evaluation is the key concern for the study to improve organization efficiency and accountability. The main objective of the study is to evaluate bank's performance in context of 15 Pakistani banks by selecting panel data from 2009 to 2013 . The study uses two proxies of profitability (ROA and ROE) to measure the performance of the banking industry in Pakistan.

\subsection{Objectives of the Study}

The study objectives are as

- To identify the main determinants of bank's performance in Pakistan.

- To evaluate the effect of micro factors (e.g.; investment to total assets, leverage, net performing loan to gross advances, capital ratio and total deposit to total equity) on Return on Assets (ROA).

- To assess the relationship of internal factors (e.g.; investment to total assets, leverage, net performing loan to gross advances, capital ratio and total deposit to total equity) with Return on Equity(ROE).

\section{Literature Review}

\subsection{Determinants of Profitability}

Philip Molyneux and Seth(1998) investigate the relationship of bank size with profitability, which depicts that banks size is dependent on the economies of scales, because large banks are more profitable than small banks. Demirguc-Kunt, Levine, and Min(1998) illustrate that higher fund would facilitate the banks to deliver and provide more loan lead to higher profitability. Molyneux and Thornton (1992) have determined the determinants of banks performance and concluded that profitability and interest rate are positively related with Return on Assets (ROA). Thus, they have also exhibited that banks pay higher interest on deposit to get and attract more funds from the potential stakeholders. Havrylchyk and Jurzyk (2006) have selected a sample of 265 banks in central and Eastern European countries over the period of 1995 -2003. They have examined the differences in profitability among foreign and domestic banks. They have also found that foreign banks earned higher profit than domestic banks. In addition, profitability of foreign banks has less affected by macroeconomics condition. Pasiouras and Kosmidou (2007) have shown that specific to banking characteristics and overall environment affect profitability of domestic and foreign banks. Furthermore, they have revealed that profitability of both domestic and foreign banks has been affected by the financial market structure and macroeconomics conditions. 
Athanasoglou, Brissimis, and Delis(2008) have demonstrated that bank size and business cycle have been positively influenced the bank's profitability and credit risk, operating efficiency, higher debt turnover and high real rate of interest are positively associated with profitability (Ramlall, 2009). Furthermore, loan, equity, and deposit have a robust influence on bank profitability(Javaid, 2011). Therefore, higher loan has no significant effect on profitability, however, deposit and equity have a significantly positive influence on banks' profitability. Hence, higher cost of production and higher total assets may not necessarily lead to higher profit. Bintawim Samar Saud(2011) has studied internal factors of the Saudi Banks and found that large banks have achieved a tremendous growth rate than medium size banks. Further they have explained that banks' size is negatively associated with bank profitability, while assets utilization has a positive effect on bank performance. Ramadan, Kilani, and Kaddumi (2011), have examined the relationship of bank profitability with internal and external factors. They have documented that bank profitability is associated with low credit risk, high lending activities and efficient cost management. Rahman et al. (2012), have conducted a study on 26 conventional and Islamic banks by using regression models over the period of 2006-2011. The empirical results have shown that size of the bank, capital and loan have significant impact on the performance of the selected banks. Size is negatively related while capital and loan are positively related with profitability while deposits have insignificant effect on the performance of banks. A study on the internal factors such as cost, size and liquidity of Sudan banks has concluded that cost, size and liquidity influence profitability of the banks (Eljelly, 2013).

Iatridis and Persakis(2012), have examined the before and after effects of implementing IAS ${ }^{1} 32$, IAS 39 and IFRS 7 by taking samples from UK and Greek banks. They have found that profitability of banks are influenced by size, capital and efficiency. Jan et al. (2014) have used two proxies of profitability (ROA and ROE) of insurance industry over the period of 2010-2013 by using multivariate regression model. The researchers have concluded that gearing ratio, NPLs ratio and asset management have significant affect on profitability of insurance industry in Pakistan across both proxies i.e return on assets and return on equity. Almazari (2014) has observed the internal factors of banks that affect profitability of Saudi and Jordanian banks over the period of 2005 to 2011 by employing financial ratios, Pearson's correlation and regression analysis. He has revealed a positive relationship between return on asset and liquidity risk. On the other hand, negative relationship been found among net credit facility to total asset, net credit facility to credit ratio, cost income ratio and bank size. Jaber and Al-khawaldeh (2014), have studied the internal and external factors of commercial banks in Jordan over the period of 2007-2012. They have documented a positive and significant relationship of capital adequacy, size and liquidity with ROA.

\subsection{Return on Assets (ROA)}

The Return on Asset (ROA) is an effective determinant of bank's profitability determined by net income to total assets. In addition, ROA demonstrates the revenue earned per dollar of assets reflecting the bank's administrative skills to use its financial

\footnotetext{
${ }^{1}$ International accounting standard (IAS) 
and real investment resources in producing income (Ben Naceur, 2003; Alkassim, 2005).

\subsection{Return on Equity (ROE)}

The Return on equity (ROE) refers to the amount that business gains by employing their shareholder equity. It determines the shareholder rate of return on their financial investment. Therefore, higher ratio indicates that business is capable of generate money internally, hence, higher rate of ROE is better than the low rate. Return on Equity ratio represents the rate of return on the investment by shareholder, which indicates the management ability in terms of proper utilizing of shareholder investment (Khrawish, 2011).

\subsection{Capital Adequacy}

Capital is one of the company specific aspects that can affect earnings. According to P. Athanasoglou, Brissimis, and Delis (2008) capital is the amount that is available and could be employed to improve business as well as act particularly in case of hostile condition. It generates liquidity and reduces the chance of undesirable conditions. The sufficiency of capital is evaluated through the capital ampleness that reveals strength and profitability of the organization.

\subsection{Non-Performing Loan Ratio}

Bank's assets are integration of current assets, fixed assets and others; one of the variables that influence profitability. Banks' loan is a leading resource that generates earnings. As by Dang (2011) the uppermost risk encounter by banking institutions would be the losses resulted from antisocial or delinquent loan. Thus, the best proxy for the asset quality is the nonperforming loan ratio. It's a major concern for most banking institutions to maintain the low level nonperforming loan as the high loans affect bank earnings. The lower the ratio the better may be the bank's efficiency.

\subsection{Bank Liquidity}

"Liquidity is an elusive notion therefore, it is easier to recognize than define" According to $\operatorname{Sarb}(2012)$ the liquidity can be defined in three ways, (i) financial instruments exchange for money without any loss of value, (ii) trading of an asset without any price concession and, (iii) monetary liquidity is circulating in the economy.

\subsection{Capital Ratio}

Capital serves as a source of funds along with borrowing and deposit for banks (Rasiah, 2010). The banks' assets can be financed with two sources i.e. debt financing and internal financing (capital). Using the large amount of debt financing the banks may experience reduction in profitability, bankruptcy and problem of liquidity. Alternatively, banks with enough capital can take higher risks, absorb shocks originated from liquidity and credit risk. Sufian and Chong(2008) have claimed that banks in developing countries require strong capital structure and high level of equity to reduce the cost of capital and to enhance profitability. On the other hand, the lower level of equity and capital have negative impact on profit causing low performing banks.

${ }^{2}$ Andrew Crockett in this issue of the Financial Stability Review. 


\section{Research Methodology}

\subsection{Data Collection, Analysis and Presentation}

All the banks works under the rules and regulation of State Bank of Pakistan (SBP) and publish annual reports for all the stakeholders. Therefore, the secondary data of fifteen banks have been randomly selected in the study. The data of the selected banks have been obtained from the financial statements of the banks over the study period 2009 to 2013. Furthermore, the panel data technique i.e. fixed-effect and random-effect models have been used to analyze the effects on performance and to determine the financial performance of banking sector in Pakistan.

\subsection{Models}

As given in Table 1, Return on Asset (ROA) and Return on Equity (ROE) have been used as dependent variables in the study. However, explanatory variables are investment to total asset ratio, total liability to total asset ratio, non-performing loans to gross advances, capital ratio and total deposit to total equity ratio. Thus, fixed-effect and random-effect models are employed with panel (time series and cross sectional) data.

$$
\begin{aligned}
& \text { ROA }=\beta_{\mathrm{o}}+\beta_{1} \text { ITAit }+\beta_{2} \text { TLTAit }+\beta_{3} \text { NPL GAit }+\beta_{4} \text { CRit }+\beta_{5} \text { TDTEit }+ \text { uit } . \\
& \text { ROE }=\beta_{\mathrm{o}}+\beta_{1} \text { ITAit }+\beta_{2} \text { TLTAit }+\beta_{3} \text { NPL GAit }+\beta_{4} \text { CR }+\beta_{5} \text { TDTE }+ \text { uit } \ldots .
\end{aligned}
$$

Table 3.1: Measurements and Variables of the Study

\begin{tabular}{|lll|}
\hline Variables & Scales & \multicolumn{1}{c|}{ Proxies } \\
\hline Dependent & Return on Assets & ROA \\
& & \\
& Return on Equity & ROE \\
Independent & Investment in Total Asset & ITA \\
$\mathbf{1}$ & & \\
$\mathbf{2}$ & Total Liability to Total Asset & TL/ TA \\
$\mathbf{3}$ & Non-Performing Loan to Gross Advances & NPL / GA \\
$\mathbf{4}$ & Capital Ratio & CR \\
$\mathbf{5}$ & Total deposit to Total Equity & TD / TE \\
\hline
\end{tabular}

\section{Results and Discussions}

Table 4.2 highlights the descriptive statistics of variables used in the study. As described in Table 3.1, return on asset and return on equity are dependent variables, whereas, investment to total asset, total liability to total asset, NPL to gross advances, capital ratio and total deposit to total equity are independent variables. All the variables have a positive mean value range from a 07.586 to 90.178 percent. The standard deviation of the variables shows that all observations in a data set are more close to the mean. The highest standard deviation of ROE and total deposit to total equity is 39.004 and 43.653 respectively. It indicates that there is a greater variation in the data set of ROE and total deposit to total equity ratio. It has been observed that some banks are well established and employ high deposits and equity that increase banks ROE and total deposit to equity. All other variables of the study have a low standard deviation and their values are close to their mean value indicating the consistency of the data. 
Table 4.1: Descriptive Statistics (No of Observations=75)

\begin{tabular}{|lcllll|}
\hline & N & Minimum & Maximum & Mean & Std. Deviation \\
\hline ROE & 75 & -198.90 & 234.71 & 07.5861 & 39.00398 \\
ROA & 75 & -005.41 & 003.06 & 00.5315 & 01.45586 \\
Investment to Total Asset & 75 & 007.98 & 058.02 & 34.5100 & 10.74836 \\
Total Liability to Total & 75 & 062.78 & 098.42 & 90.1779 & 05.43216 \\
Asset & & & & & \\
NPL to Gross Advances & 75 & 001.91 & 051.56 & 12.0836 & 09.30075 \\
Capital Ratio & 75 & -003.10 & 036.91 & 08.7709 & 05.67206 \\
Total Deposit to Total & 75 & -042.00 & 376.00 & 13.8000 & 43.65300 \\
Equity & & & & & \\
Valid N (list wise) & 75 & & & & \\
\hline
\end{tabular}

Source: Output of STATA software (data from financial statement of banks 2009- 2013)

Table 4.2 presents correlation matrix of dependent and independent variables used in the study. Moreover, in the data set there is no missing values, all correlations are based on 75 observations. Return on asset has positive correlation with investment to total assets, total liability to total assets, total deposit to total equity. However, Return on assets have negative relationship with NPL to Gross advance and capital ratio.

Table 4.2: Correlation Matrix between Variables of the Study (Obs. = 75)

\begin{tabular}{|lllllll|}
\hline & 1 & 2 & 3 & 4 & 5 & 6 \\
\hline 1.ROE & 1 & & & & & \\
2.Investment to Total Asset & 0.296 & 1 & & & & \\
$\begin{array}{l}\text { 3.Total Liability to Total } \\
\quad \text { Asset }\end{array}$ & 0.011 & 0.125 & 1 & & & \\
$\quad$ 4.NPL to Gross Advances & -0.159 & -0.115 & 0.137 & 1 & & \\
$\begin{array}{l}\text { 5.Capital Ratio } \\
\text { 6.Total Deposit to Total }\end{array}$ & -0.060 & -0.151 & -0.563 & -0.295 & 1 & \\
$\quad$ Equity & 0.669 & 0.017 & 0.160 & 0.098 & -0.166 & 1 \\
\hline
\end{tabular}

Source: Output of stata software (data from financial statements of banks 2009- 2013)

All the numerical values are less than six indicating no collinearity problem between variables. Investment to total asset NPL to Gross advance and capital ratio has negative correlation in the study, while other variables are positive correlated with investment to total asset. Moreover, total liability to total asset is negatively correlated with numerical value of -0.5634 and NPL to Gross Advances and capital ratio are inversely related with empirical value of -0.295. All the remaining variables are positively correlated except capital ratio with total deposit to total assets. As evidence in table 3 , the correlation between investment to total asset, total liability to total asset, and total deposit to total equity ratio has been found positive with ROE. The results are consistent with the studies of Rahman et al. (2012), Jaber \& Al-khawaldeh (2014) and Jan et al. (2014). Conversely, the correlation between NPL to gross investment, capital 
ratio and ROE has been noticed negative. Table 4.3 exhibits that investment to total assets has positive and significant influence on Return on assets with p-value $<0.005$. However, the coefficient value is 00.7139 , which indicates that one unit increase in the value of investment to total assets could incline 71 percent of return on assets. This relationship is congruent with the findings of P. P. Athanasoglou, Brissimis and Delis(2008) and Jaber \& Al-khawaldeh(2014). Leverage has inverse and significantly influence on profitability of Pakistani banks. Therefore, the t-value is -04.62 , and coefficient value -10.7166 , which shows that increase in the value of leverage would reduce return on assets. This result is inconsistent with prior studies such as Demirguc-Kunt, Levine, and Min(1998), Ramlall(2009) and Rahman et al. (2012). NPL to gross advance has negative and significantly related with return on assets of banking sector with p-value 0.000 and coefficient value of -01.8338 . Hence, increase in the value of NPL to gross advance could decrease the percentage return on assets of banks. The significant relationship of NPL to gross advance is also consistent with results of Jan et al. (2014). The capital ratio of banks has inverse but significant association with profitability (ROA). Table 4 show tvalue of capital ratio -04.38 and coefficient value -10.1838 , respectively. Rahman et al. (2012) also support the significant influence of capital ratio and performance in Pakistani Banks. Total deposit to total equity has positive and significant influence on return on assets with highest value of $t$ i.e. 09.99 and coefficient value 00.0062 . This result is stand in line with the findings of Javaid (2011).

Table 4.3: Random-effect GLS Regression Model

\begin{tabular}{|c|c|c|c|c|c|c|}
\hline \multirow{3}{*}{$\begin{array}{l}\text { ROA } \\
\text { Investment to Total } \\
\text { Asset }\end{array}$} & & \multicolumn{2}{|c|}{$\begin{array}{l}\text { Number of Obs } \\
\text { Number of Groups } \\
\text { Obs Per Group: } \\
\text { Min } \\
\text { Avg } \\
\text { Max } \\
\text { Wald chi2(5) } \\
\text { Prob > chi2 }\end{array}$} & & \multicolumn{2}{|c|}{$\begin{array}{l}=5.00 \\
=5.00 \\
=5.00 \\
=140.19 \\
=0.0000\end{array}$} \\
\hline & Coef. & Std. Err. & $\mathbf{t}$ & P> l t l & {$[95 \%$ Cor } & nf. Interval] \\
\hline & 00.714 & 0.264 & 02.71 & 0.007 & 00.1970 & 1.2309 \\
\hline $\begin{array}{l}\text { Total Liability to Total } \\
\text { Asset }\end{array}$ & -10.717 & 2.321 & -04.62 & 0.000 & -15.2648 & -6.1683 \\
\hline NPL to Gross Advances & -01.834 & 0.385 & -04.76 & 0.000 & -02.5882 & -1.0794 \\
\hline Capital Ratio & -10.184 & 2.323 & -04.38 & 0.000 & -14.7371 & -5.6305 \\
\hline $\begin{array}{l}\text { Total Deposit to Total } \\
\text { Equity }\end{array}$ & 00.006 & 0.006 & 09.99 & 0.000 & 00.0050 & 0.0075 \\
\hline Cons. & 52.522 & 2.342 & 04.49 & 0.000 & 05.9319 & 15.1125 \\
\hline
\end{tabular}

Source: Output of stata software ( data from financial statement of banks 2009-2013) 
Table 4.4 displays the empirical results of Return on Equity with explanatory variables. Investment to total assets are positive and significantly related with Return on equity with $\mathrm{p}$ value 0.010 and coefficient value i.e. 00.9191 . The coefficient value indicates that one unit increase in the value of investment to total assets would increase 91 percent in Return on equity. Thus this results are congruent with the study of (Jaber \& Alkhawaldeh, 2014).

Total liability to total assets is significant and inversely associated with profitability of the banks. The t-value is -04.90 and coefficient value is -13.5916 , which compile that increase in the value of Leverage would decrease return on equity. On the other hand, NPL to Gross Advance finds insignificant but positive influence on Return on assets of banks. Capital ratio has significant and positive impact on return on assets with t-value of -05.01 and coefficient value is -13.5711 , respectively. Thus, this finding is consistent with the results of Rahman et al.(2012). Total deposit to total equity is positive and significantly influencing on return on equity of Pakistani banks. The highest value of t i.e. 12.20, confirms strong impact of total deposit to total equity. This results are consistent with the findings of Javid(2011).The overall result indicates that increase in investment, NPL and deposit have a positive effect on Return on equity and Liability and capital ratio have a negative effect on the ROE. The overall variation in the model has a significant effect except capital ratio, which p-value is $>0.005$.

\section{Table 4.4 : Fixed-effect Model}

\begin{tabular}{|c|c|c|c|c|c|}
\hline \multirow[b]{2}{*}{ ROE } & & $\begin{array}{l}\mathrm{Fix} \\
\mathrm{Nu} \\
\mathrm{Nu} \\
\mathrm{Ob} \\
\mathrm{Mi} \\
\mathrm{Av} \\
\mathrm{Ma} \\
\mathrm{F}( \\
\mathrm{Prc}\end{array}$ & $\begin{array}{l}\text { d-effects } \\
\text { ber of } \mathrm{Ol} \\
\text { ber of } \mathrm{Gr} \\
\text { Per Grou } \\
\text { 55) } \\
>\mathrm{F}\end{array}$ & $\begin{array}{l}\text { vithin) } \mathrm{R} \\
\text { ups }\end{array}$ & $\begin{array}{l}=75 \\
=15 \\
=5.00 \\
=5.00 \\
=5.00 \\
=39.49 \\
=0.000\end{array}$ \\
\hline & Coef. & Std. Err. & $\mathbf{T}$ & P> l t l & [95\% Conf. Interval] \\
\hline Investment to Total Asset & 00.919 & 0.345 & 02.67 & 0.010 & $00.2283 \quad 1.6097$ \\
\hline Total Liability to Total Asset & -13.592 & 2.772 & -04.90 & 0.000 & $-19.1463-8.0371$ \\
\hline NPL to Gross Advances & 00.775 & 0.830 & 00.93 & 0.354 & -00.88842 .4386 \\
\hline Capital Ratio & -13.571 & 2.719 & -05.01 & 0.000 & $-19.0039-8.138$ \\
\hline Total Deposit to Total Equity & 00.007 & 0.001 & 12.20 & 0.000 & 00.00620 .0087 \\
\hline Cons. & 13.010 & 2.768 & 04.70 & 0.000 & $07.4632 \quad 18.557$ \\
\hline
\end{tabular}

Source: Output of stata software (data from financial statement of banks 2009-2013)

\section{Conclusion}

The study has investigated the impact of internal factors on banks performance by using two proxies i.e. Return on Assets and Return on Equity in banking sector of Pakistan for the study period of 2009-2013. The data has been collected from the financial statements of the selected banks. Panel data technique is used to identify the impact of explanatory variable on performance. Hausman test has selected that Random effect model is appropriate for Return on Equity, however fixed effect model is prominent for Return on Equity. Investment to total assets, total liability to total assets, capital ratio and total deposit to total equity are significant Bank-level factors across both proxies 
(ROA and ROE). However, NPL to gross advance is significant with return on assets and insignificant on return on equity. The results are worthy for bankers and all stakeholders to make strategic decision for the competitiveness of banking sector in Pakistan. Practically the study may help bank decision makers to focus on the major banking activities that may increase the bank ranking and financial performance positions comparing with other banks. The findings should assist the management of commercial banks in crafting applicable financial strategies to realize the required planned financial performance. The future directions suggest an investigation into the impact of ownership on bank efficiency that is the difference in performance of banks domestically as well as internationally owned.

\section{References}

Albertazzi, U., \& Gambacorta, L. (2009). Bank profitability and the business cycle. Journal of Financial Stability, 5(4), 393-409.

Almazari, A. A. (2014). Impact of Internal factors on bank profitability: Comparative study between Saudi Arabia and Jordan. Journal of Applied Finance \& Banking, 4(1), 125-140.

Alkassim, F. A. (2005). The Profitability of Islamic and Conventional Banking in the GCC Countries: AComparative Study.

Athanasoglou, P., Brissimis, S., \& Delis, M. (2008). Bank-specific, industry-specific and macroeconomic determinants of bank profitability. Journal of International Financial

Athanasoglou, P. P., Brissimis, S. N., \& Delis, M. D. (2008). Bank-specific, industryspecific and macroeconomic determinants of bank profitability. Journal of International Financial Markets, Institutions and Money, 18(2), 121-136.

Ben Naceur, S. \& Goaied, M. (2005). The Determinants of Commercial Bank Interest Margin and Profitability: Evidence from Tunisia.

Bintawim ,S. S. S. (2011). Performance analysis of Islamic banking: Some evidence from Saudi Arabian banking sector. Ritsumeikan Asia Pacific University.

Dang, U. (2011). The CAMEL Rating System in Banking Supervision: a Case Study of Arcada University of Applied Sciences. International Business.

Demirguc-Kunt, A., Levine, R., \& Min, H. (1998). Opening to Foreign Banks: Issues of Stabili, Efficiency, and Growth.

Eljelly, A. M. A. (2013). Internal and external determinants of profitability of Islamic banks in Sudan: evidence from panel data. Afro-Asian Journal of Finance and Accounting, 3(3), 222-240.

Gitman, L. J. (2007). Principles of Managerial Finance (12th ed.): Addison Wesley.

Havrylchyk, O., \& Jurzyk, E. M. (2006). Profitability of foreign banks in Central and Eastern Europe: Does the entry mode matter?

Iatridis, G. E., \& Persakis, A. D. (2012). Bank profitability determinants under IFRSs. International Journal of Economics and Accounting.

Jaber, J. J., \& Al-khawaldeh, A. A. (2014). The Impact of Internal and External Factors on Commercial Bank Profitability in Jordan. International Journal of Business and Management, 9(4), p22. 
Jan, S., Iqbal, K., \& ur Rahman, S. (2014). Determinants of Profitability of Islamic and conventional Insurance Companies in Pakistan: an Internal Evaluation. Abasyn University Journal of Social Sciences, 7(1).

Javaid, S. (2011). Determinants of bank profitability in Pakistan: Internal factor analysis. Mediterranean Journal of Social Sciences, 59.

Khrawish, H. (2011). Determinants of commercial banks performance: evidence from Jordan. International Research Journal of Finance and ....

Molyneux, P., \& Seth, R. (1998). Foreign banks, profits and commercial credit extension in the United States. Applied Financial Economics, 8(5), 533-539.

Molyneux, P., \& Thornton, J. (1992). Determinants of European bank profitability: A note. Journal of Banking \& Finance.

Murthy, Y., \& Sree, R. (2003). A Study on Financial Ratios of major Commercial Banks. Research Studies, College of Banking \& Financial Studies, Sultanate of Oman.

Pilloff, S. J., \& Rhoades, S. A. (2002). Structure and profitability in banking markets. Review of Industrial Organization, 20(1), 81-98.

Rahman, S. U., Jan, F. A., Iqbal, K., \& Ali, Z. (2012). Parameters of conventional and Islamic insurance companies' profitability: Evaluation of internal Analysis. Research Journal of Finance and Accounting, 3(3), 11-18.

Ramadan, I. Z., Kilani, Q. A., \& Kaddumi, T. A. (2011). Determinants of bank profitability: Evidence from Jordan. International Journal of Academic Research, 3(4), 180-191.

Ramlall, I. (2009). Bank-specific, industry-specific and macroeconomic determinants of profitability in Taiwanese banking system: under panel data estimation. International Research Journal of Finance and Economics, 34, 160-167.

Rasiah, D. (2010). Theoretical framework of profitability as applied to commercial banks in Malaysia. European Journal of Economics, Finance and Administrative Sciences, 19(19), 75-97.

Sarb. (2012). Financial Stability Review Financial Stability Review, (March).

SBP (2009). State Bank of Pakistan, Banking Sectors Supervision in Pakistan.

Sufian, F., \& Chong, R. R. (2008). Determinants of bank profitability in a developing economy: empirical evidence from the Philippines. Asian Academy of Management Journal of Accounting and Finance, 4(2), 91-112. 